\title{
Possible sequelae in post-SARS-CoV-2 patients: effects on sleep and general health condition
}

\author{
Bárbara Virginia Vitti-Ruela ${ }^{1}$ - Vinícius Dokkedal-Silva ${ }^{2}$ - Daniela Santoro Rosa ${ }^{3} \cdot$ Sergio Tufik $^{2}$. \\ Monica Levy Andersen ${ }^{2}$ (I)
}

Received: 11 June 2020 / Revised: 8 July 2020 / Accepted: 17 July 2020 / Published online: 22 July 2020

(C) Springer Nature Switzerland AG 2020

\section{Dear Editor,}

The world has been the stage for a new coronavirus, officially named severe acute respiratory syndrome coronavirus 2 (SARS-CoV-2), causing the coronavirus disease 2019 (COVID-19). As the discovery of SARS-CoV-2 is very recent, there are few reliable studies on the long-term consequences of exposures of this virus. In view of this turbulent global scenario and the need for more research, it is clear that a greater focus on this theme is urgent.

Currently, 7 human coronaviruses have been identified, among which were previously described severe acute respiratory syndrome-CoV (SARS-CoV) and Middle East respiratory syndrome-CoV (MERS-CoV), the 2 most recognized following the outbreaks in 2003 and 2012, respectively [1].

The structural homology of SARS-CoV-2 with SARS and the similarity in their clinical conditions have been noted, leading us to believe that individuals infected by SARSCoV-2 may present abnormalities similar to those presented in SARS. A number of studies highlighted several sequelae after the acute phase of SARS related to radiological and functional abnormalities, such as shortness of breath and disturbed sleep [2-4].

Until now, it is known that SARS-CoV-2 is responsible for leading to acute respiratory distress syndrome, kidney and heart failure, liver damage, shock, and multiple organ failure [5]. The severity of symptoms in COVID-19 may be associated with a pro-inflammatory cytokine storm, also seen in

Monica Levy Andersen

ml.andersen12@gmail.com

1 Faculdade de Medicina de Marília, Marília, Brazil

2 Departamento de Psicobiologia, Universidade Federal de São Paulo (UNIFESP), Rua Napoleão de Barros, 925, São Paulo 04024-002, Brazil

3 Departamento de Imunologia, Universidade Federal de São Paulo, São Paulo, Brazil
SARS, which is responsible to generate the systemic inflammation [5]. A higher serum concentration of these cytokines in patients in intensive care units corroborates this possible relationship [6]. The severity of the clinical presentation also appears to be related to the underlying diseases, such as cardiovascular diseases and obstructive sleep apnea (OSA) [5, 7]. A recent study proposed that OSA, the most common sleeprelated breathing disorder, may be one of these conditions that can be considered a potential risk factor for severe COVID-19 [7].

The long-term impact of COVID-19 is still under investigation, and little is known about how the immune system recovers after infection. Scientific evidence suggests the possibility of a high residual viral load of SARS-CoV-2 in convalescent patients [8]. So far, clinical studies have been shown the occurrence of extensive lung damage, pulmonary inflammation, and hyperinflammatory response of the body $[5,6,9]$. However, long-term follow-up is needed to determine whether this impairment of lung tissue is irreversible. Besides, studies have shown that coronaviruses are capable of infecting neurons by binding to the angiotensin-converting enzyme receptor 2 (ACE2) expressed by neural cells. These receptors are also found in the lung, small bowel, and vasculature, among others $[3,10,11]$.

The entry of the coronavirus into the central nervous system and peripheral tissues can lead to respiratory insufficiency due to neuroinvasion in the brainstem, responsible for cardiorespiratory control [10]. The prolonged effects of impaired respiratory regulation, due to neurological injury, can result in a worsening of the quality of sleep in patients recovering from COVID-19, since there is a close relationship between breathing disorders and sleep [12]. In this sense, the infection can also play a role in the appearance of sleep disorders in survivors after SARS-CoV-2.

Supporting the concern with post-infection sleep quality, a study in Toronto, Canada (2011), identified, among other symptoms, changes in sleep patterns in post-SARS patients. 
An increase in nonrestorative sleep with associated REMrelated apneas/hypopneas, a high alternating cyclic pattern of sleep EEG and anomaly of alpha EEG sleep, was observed [4]. Due to the similarities in the pathophysiological processes, SARS-CoV-2 may also cause these sleep changes.

The long-term adverse effects of COVID-19 are unknown, so further clinical trials focusing on possible pulmonary sequelae, sleep patterns, and neurocognitive and neuropsychiatric impairment of these patients are necessary. We would like to emphasize that neurological injury caused by coronaviruses can lead to damage to respiratory regulation, which is close to breathing-related sleep disorders. In this sense, a worsening of sleep quality in patients recovering from COVID-19 may occur. In a scenario in which the number of cases and cured cases rises significantly every day, it is crucial that particular attention is given to the recuperation of patients infected with SARS-CoV-2.

Authors' contributions B.V.V. was responsible for the conceptualization of the manuscript, the literature research, and for writing the original draft. V.D.S. has supervised manuscript production and performed revision and correction of the manuscript. D.S.R. has participated in the literature research and revised the manuscript. S.T. gathered resources for manuscript preparation and was responsible for project administration. M.L.A. has revised the manuscript and coordinated manuscript production.

Funding information This work was supported by grants from the Associação Fundo de Incentivo à Pesquisa (AFIP). M.L.A. and S.T. are CNPq fellowship recipients.

\section{Compliance with ethical standards}

Conflict of interest The authors declare that they have no conflicts of interest.

\section{References}

1. Chang L, Yan Y, Wang L (2020) Coronavirus disease 2019: coronaviruses and blood safety. Transfus Med Rev 34:75-80. https://doi.org/10.1016/j.tmrv.2020.02.003

2. Chan KS, Zheng JP, Mok YW, Li YM, Liu YN, Chu CM, Ip MS (2003) SARS: prognosis, outcome and sequelae. Respirology 8 Suppl(Suppl 1):S36-S40. https://doi.org/10.1046/j.1440-1843. 2003.00522.x
3. Bhayana R, Som A, Li MD, Carey DE, Anderson MA, Blake MA, Catalano O, Gee MS, Hahn PF, Harisinghani M, Kilcoyne A, Lee SI, Mojtahed A, Pandharipande PV, Pierce TT, Rosman DA, Saini S, Samir AE, Simeone JF, Gervais DA, Velmahos G, Misdraji J, Kambadakone A (2020) Abdominal imaging findings in COVID19: preliminary observations. Radiology:201908. https://doi.org/ 10.1148/radiol.2020201908

4. Moldofsky H, Patcai J (2011) Chronic widespread musculoskeletal pain, fatigue, depression and disordered sleep in chronic postSARS syndrome; a case-controlled study. BMC Neurol 11:37. https://doi.org/10.1186/1471-2377-11-37

5. Zaim S, Chong JH, Sankaranarayanan V, Harky A (2020) COVID19 and multiorgan response. Curr Probl Cardiol:100618. https://doi. org/10.1016/j.cpcardiol.2020.100618

6. Huang C, Wang Y, Li X, Ren L, Zhao J, Hu Y, Zhang L, Fan G, Xu J, Gu X, Cheng Z, Yu T, Xia J, Wei Y, Wu W, Xie X, Yin W, Li H, Liu M, Xiao Y, Gao H, Guo L, Xie J, Wang G, Jiang R, Gao Z, Jin Q, Wang J, Cao B (2020) Clinical features of patients infected with 2019 novel coronavirus in Wuhan, China. Lancet 395(10223):497506. https://doi.org/10.1016/S0140-6736(20)30183-5

7. Tufik S, Gozal D, Ishikura IA, Pires GN, Andersen ML (2020) Does obstructive sleep apnea lead to increased risk of COVID-19 infection and severity? J Clin Sleep Med 0 (0):jcsm.8596. https:// doi.org/10.5664/jcsm. 8596

8. Rothe C, Schunk M, Sothmann P, Bretzel G, Froeschl G, Wallrauch C, Zimmer T, Thiel V, Janke C, Guggemos W, Seilmaier M, Drosten C, Vollmar P, Zwirglmaier K, Zange S, Wölfel R, Hoelscher M (2020) Transmission of 2019-nCoV infection from an asymptomatic contact in Germany. N Engl J Med 382(10): 970-971. https://doi.org/10.1056/NEJMc2001468

9. Shi H, Han X, Jiang N, Cao Y, Alwalid O, Gu J, Fan Y, Zheng C (2020) Radiological findings from 81 patients with COVID-19 pneumonia in Wuhan, China: a descriptive study. Lancet Infect Dis 20:425-434

10. Li YC, Bai WZ, Hashikawa T (2020) The neuroinvasive potential of SARS-CoV2 may play a role in the respiratory failure of COVID-19 patients. J Med Virol 92:552-555. https://doi.org/10. 1002/jmv. 25728

11. To KF, Lo AW (2004) Exploring the pathogenesis of severe acute respiratory syndrome (SARS): the tissue distribution of the coronavirus (SARS-CoV) and its putative receptor, angiotensinconverting enzyme 2 (ACE2). J Pathol 203(3):740-743. https:// doi.org/10.1002/path.1597

12. Dyken ME, Yamada T, Berger HA (2003) Transient obstructive sleep apnea and asystole in association with presumed viral encephalopathy. Neurology 60(10):1692-1694. https://doi.org/10.1212/ 01.wnl.0000064166.82077.eb

Publisher's note Springer Nature remains neutral with regard to jurisdictional claims in published maps and institutional affiliations. 